\title{
Landfill Site Selection via Geographical Information System and Fuzzy Logic in Uşak Province (Turkey)
}

Mehmet Deniz ( $\nabla$ mehmet.deniz@usak.edu.tr)

Uşak Üniversitesi https://orcid.org/0000-0002-7696-045X

\section{Research Article}

Keywords: site selection, landfill, geographical information system (GIS), fuzzy logic

Posted Date: July 28th, 2021

DOl: https://doi.org/10.21203/rs.3.rs-710598/v1

License: (c) (i) This work is licensed under a Creative Commons Attribution 4.0 International License. Read Full License 


\section{Abstract}

The importance of landfill site selection has grown rapidly in recent years. New and various analytical techniques have also been developed due to recently conducted research. The techniques that have been developed for landfill site selection have been shaped according to the possibilities of the current time. In more recent years, along with breakthroughs in information systems technology, computer-assisted work designs and analytical techniques have come to the forefront. The intention of this study is to identify the best locations to serve as a landfill site across the provincial territory of Uşak, Turkey, while also making use of these modern technologies. This study utilizes the fuzzy logic methodology which has become common in recent years. The criteria set out in this study was digitalized through the design of base maps. ArcGIS 10.2 software was used for the formation of fuzzy membership values and fuzzy overlay procedures. The criteria that are common in the literature for fuzzy logic includes roads, rivers, airports, settlements, faults and landslides, slope, geology, soil, land use capability, and land use. As a result of this study, suitable and unsuitable locations for the purpose of landfilling were identified and mapped. These analyses show that the most optimal locations to serve as a landfill site are mostly located in the southwestern part of the Uşak province

\section{Introduction}

The importance of sustainability was magnified and gained a heightened sense of urgency around the world after the Our Common Future (Brundtland Report) was released in 1987 by the World Commission on Environment and Development (WCED) (Łozowicka 2020). From the discovery of agriculture to the present day, the ability of mankind to transform and reorganize the tangible world peaked with the Industrial Revolution. Although the devastating effects of this Revolution, which began in the second half of the 1700s, was discovered early on, it was not until the 1900s that people realized how the enormous amounts of pollution put species and environments at risk. By the late 20th century, pollution was at such high levels around the world that major counteractions were required.

The excessive overconsumption of resources following the Industrial Revolution, the tradition of manufacturing and accumulating a surplus of product, as well as unconsumed products becoming residual were the critical factors leading to the concept of sustainability. Once people took notice of the adverse consequences of those actions and their reliance on irreversible consumption, the concept of sustainability was taken into more serious consideration by multiple disciplines, including social, cultural, and financial. Ever-growing consumption not only caused a rapid depletion of global resources but also negatively impacted financial institutions, companies and organizations, culture, environment, population, etc. This is accurately summarized by Egger (2006) with the rise of overconsumption, a decline in the carrying capacity of the world will be observed.

The term 'sustainability' appears to be a complex concept with no clear definition (Azapagic and Perdan 2000, p. 243; Egger 2006; Vesela Veleva and Ellenbecker 2001, p. 519); however, the term should be clarified and developed (Vesela Veleva and Ellenbecker 2001). The nature of the term 'sustainability', implies that it must be in a constant state of transformation (Łozowicka 2020, p. 2). Due to the fact that this term is 
multifaceted, defining it succinctly has proven complicated. However, sustainability must become one of the main paradigms if we are to continue to advance society and maintain diversity (social, cultural, financial, etc.) for future generations.

Sustainability, therefore, requires the consideration of the future. Most importantly, industrial businesses must adopt sustainable manufacturing systems (Azapagic and Perdan 2000, p. 243; Krajnc and Glavič 2003 , p. 280); this necessitates robust top management, government support, and high consumer motivation (Vesela Veleva and Ellenbecker 2001, p. 532). Demanding the renewable use of resources is also of utmost importance (Rosenberg et al. 1993, p. 828). Veleva et al. (V Veleva et al. 2001, pp. 451-452) noted that the manufacturing aspect of sustainability is based on minimal material use, ecologicallyminded manufacturing, minimal packaging, and recycling. With this being the case, another factor that must be taken into account is the fact that sustainable manufacturing is not simply about the use of minimal raw materials and environmentally-friendly production processes. To achieve sustainability in true sense, manufacturing must not only generate less waste but also ensure that the waste from finished products have some level of value and can be recycled.

During the United Nations Conference on the Human Environment-which was held in 1972 in Stockholmthe United Nations Environment Programme (UNEP) which intended to achieve and monitor environmental protection was approved. Raising further awareness about sustainability and examining the concept of sustainable development, Our Common Future (Brundtland Report) by the WCED was released in 1987. Then in Rio de Janeiro in 1992, at the United Nations Conference on Environment and Development (UNCED), also called the Earth Summit, the attention of the world was again placed on sustainable development. One of the outputs from this conference, known as Agenda 21, has grown into a major landmark concerning its sustainable development program (Łozowicka 2020, p. 1), especially since the concept of sustainability penetrates into almost every activity from production to consumption, particularly from an environmental point of view. As noted by Azapagic \& Perdan (Azapagic and Perdan 2000, p. 243), world governments developed sustainable development strategies covering the items of Agenda 21.

Since then, 17 Sustainable Development Goals (SDGs) have been introduced by the United Nations Security Council. To offer a solution to the many problems modern society faces, as noted by García-Feijoo (GarcíaFeijoo et al. 2020, p. 1) the 2030 Agenda was assembled between 2000 and 2015 as a part of the UN Millennium Development Goals. These 17 SDGs, which include 169 associated targets and serve as an outline until 2030, were ratified by world governments (García-Feijoo et al. 2020, p. 1; Modibbo et al. 2020; "Sustainable Development Knowledge Platform" n.d.). The fact that the 21 st century includes sustainability in every aspect of life, it has become the most important philosophy at the start of this millennium.

As we look at these 17 goals, a wide range of topics are represented-from the economy, education, and health to energy and the environment. A list of the SDGs are as follows: (1) No Poverty; (2) Zero Hunger; (3) Good Health and Well-being; (4) Quality Education; (5) Gender Equality; (6) Clean Water and Sanitation; (7) Affordable and Clean Energy; (8) Decent Work and Economic Growth; (9) Industry, Innovation, and Infrastructure; (10) Reducing Inequality; (11) Sustainable Cities and Communities; (12) Responsible 
Consumption and Production; (13) Climate Action; (14) Life Below Water; (15) Life On Land; (16) Peace, Justice, and Strong Institutions; (17) Partnerships for the Goals (United Nations n.d.).

Sustainability and Landfilling

Leading a responsible life from a sustainable perspective requires mankind to consider the physical limitations of nature on this planet (Klitgaard 2020, p. 2). Since humanity is polluting the world with what they have consumed, not considering future consequences of those actions, and pushing the limits of nature to its furthest the need to develop methods for sustainable waste management has become essential. As noted by Tchobanoglous et al (2002, p. 1.11), landfilling is the least desirable stage of waste management yet it is also currently the most advantageous for all stakeholders.

Sustainable waste management influences the relationship between nature and humanity in three main areas: ecology, economy, and society (Rodić and Wilson 2017). Additionally, health costs and government regulations could also be added to this list (Siddiqui et al. 1996). Waste management was also emphasized as an important factor for ecology and environment in Agenda 21 (“Waste management” n.d.). For this reason, environmental issues have become some of the most important points in the SDGs. One of the first steps to be taken for environmental protection is to determine how to best manage waste that has been generated out of consumption. Although some of the SDGs are only slightly related to waste management, studies show that 12 SDGs (nearly all of them) have some relationship to landfilling (Rodić and Wilson 2017). In addition, some of the goals pertain directly to waste management such as (3) Good Health and Well-being; (6) Clean Water and Sanitation; (9) Industry, Innovation, and Infrastructure; and (11) Sustainable Cities and Communities. For example, the SDG of (3) Good Health and Well-being specifies that waste must be properly stored, the utmost attention should be paid to natural and human characteristics during landfill site section, and ensures that no risk is posed to human health. If there is any failure in designating a proper landfill site such as not taking into account the ground characteristics of the landfill or its proximity to surface waters and rivers; the risk of contamination to drinking and utility water increases. Contaminated water from landfill leakage could extend beyond is original region if that same polluted water is used for irrigation purposes.

Recently, it has become more popular for research studies to focus on the future of smart cities and their management. Smart cities employ systems and technologies for infrastructure and superstructure which facilitates a more comfortable urban life. While automated systems provide more convenience, they also involve long-term projections and advanced planning. Accordingly, the site selection for landfills has become even more important. Having a rational discussion about urban management could not be plausible without also addressing waste management and the factors that influence its site selection, including air pollution, foul odor, visual pollution, and damages that could be caused to infrastructure. In fact, the collection of waste from urban settlements as well as the way in which waste is handled and separated will undoubtedly be automated and sustained as a part of any smart city in the near future. However, the top priority for such an automated system is the selection of a landfill site location which ensures that automated systems are able to function smoothly. Since it would not be possible to relocate an 
unsuitable landfill, the desired outcomes would fail to be achieved. Therefore, one of the most important steps in waste management, which relates to most of the SDGs, is the location selection of landfill sites.

While waste management and related matters have been historically acknowledged as engineering challenges, many disciplines are now taking an interest in this topic due to its multidimensionality and challenges outside of the environmental issues that are caused by waste (Kaplan Mintz and Kurman 2020; Tchobanoglous et al. 2002, p. 1.1-1.2). The fact that waste management has expanded beyond simply being a waste problem and has assumed both social and economic dimensions, has led a variety of disciplines to research the issue.

Excessive waste generation caused by population growth puts more pressure on the planetary ecosystem. This increase in waste generation has made it imperative to develop ways to contend with waste materials. Egger (2006, p. 1236) argues that the impact of waste generated by humans has a greater influence on the world than does the rising growth rates of the human population. However, altered consumption patterns coupled with rising amounts of waste from that growing population, exacerbates the generation of waste even further; statistics clearly reveal the extent of this increase. For instance, the amount of urban solid waste per capita in the United States, the world's top economic power, was 1.2 kilograms in the 1960s while it amounted to 1.9 kilograms in the 2000s (Tchobanoglous et al. 2002, p. 1.3). Given the fact that the global population was nearly 3 billion in the 1960s and is now nearly 7.5 billion, it is clear to see how profoundly the amount of waste has increased. As Zhu (Zhu et al. 2020) stated, waste generation is at an alarming level, especially in countries with intense industry such as China. Whether waste is solid or liquid, still one of the most important aspects of waste management is the site selection for landfills-which requires substantial expertise.

According to the U.S. Environmental Protection Agency (EPA) there are four stages of managing waste within the Integrated Waste Management Plan. The first of these is (1) Source Reduction, mainly aiming to reduce the amount of waste and toxicity. (2) Recycling and Composting is another strategy that reclaims reusable materials from waste. Once the amount of waste has been reduced, it can then undergo (3) Combustion or Waste Transformation to generate energy. (4) Landfilling is the final and least desirable option (Tchobanoglous et al. 2002).

Various methods have been adopted to designate locations for landfilling in Turkey. For this purpose, from a methodological standpoint fuzzy logic (Özdemir Kipel 2017) multi-criteria decision making, analytical hierarchy (Ersoy 2007), and scoring have been used. In Turkey, the number of studies that have adopted geographical information systems (GIS) has been increasing in recent years. These studies, which employed GIS, were conducted in an effort to designate eligible landfill site locations across different provinces of Turkey: Konya, Gaziantep, Samsun, Adana, Uşak, Şırnak, Afyonkarahisar, Antalya, Isparta, İstanbul, İzmir, Sivas, Trabzon, Ankara, and Kahramanmaraş (Kaplan 2002; Şener 2004; İşlek 2004; Nas et al. 2009; Deniz and Topuz 2018a; Karayılan 2018; Aksoy 2016; Dağıstanlığlu 2012; Kavaklı 2011; Bahçeci 2006; Coşkuner 1996; Yildirim 2012; Güler 2016; Kolay 2012; Öner 2019; Erdoğan 2019; Küçükönder and Karabulut 2007; Özdemir Kipel 2017; Ersoy and Bulut 2009). 
In this research field, problems concerning the location of landfill sites continue to arise. Following an environmental disaster in the district of Merkez, retrospective research was conducted and the location of a landfill was, indeed, cited as a problem (Deniz and Topuz 2018a). After the destruction of one of the wastewater treatments plants, over pollution of nearby rivers, pollution caused by industrial zones as well as facilities where urban waste is stored, and air pollution from significant industrial production the critical issues Uşak must address were exposed. The preferences for the location of landfill sites for this province had become such an issue that they were reported by the local and national Turkish press, which led to some landfills being relocated multiple times. Issues still persist despite the relocation of landfill sites and treatment plants around Uşak province because their locations were not properly selected, which is now evident. This is an example of why the proper designation of a location, by means of strictly-designated variables, is of the utmost significance, especially when considering the health and environmental problems imposed on the surrounding population. In order for Uşak to achieve some of the SDGs (Good Health and Well-being; Clean Water and Sanitation; Industry, Innovation, and Infrastructure; Sustainable Cities and Communities), the location of landfill sites must be properly designated in accordance with scientific criteria.

The intention of this study is to accurately identify eligible landfill site locations for sustainable waste management across the province of Uşak, while taking into account the literature from the field and the unique, local geographical factors. The entire province of Uşak was surveyed in order to determine the potential landfill site locations using GIS. If the designated locations could be fully evaluated in coordination with regional zone planning, the health and environmental problems could be mitigated or prevented entirely, thus, making this study imperative.

Location and general geographical features of research area

The country of Turkey consists of 81 provinces that serve as local authorities. As a part of the administrative structure, the provinces are then divided into districts that serve as small-scale authorities. The Aegean region contains 11 of those provinces, of which the study area is one: Uşak province is located in the inner-western Anatolian sub-region. This province is surrounded by Kütahya to the north, Afyonkarahisar to the east, Denizli to the south, and Manisa to the west (Fig. 1). According to the General Directorate of Mapping, it has a total territorial size of 5555 km2 (Harita Genel Müdürlügü 2020).

Within Uşak province, the unpredictable Mediterranean climate is prevalent across lower elevations while a continental climate prevails across the higher elevations. This area is hydrographically home to the headwater springs of many rivers since it is located in a higher region of western Anatolia. Situated in the northern part of the province is Murat Mountain, which is where the upper basins of Büyük Menderes, Gediz, Sakarya, and Akarçay rivers are located.

Uşak province is home to 6 total districts-Banaz, Eşme, Karahallı, Sivaslı, Ulubey, and Merkez; the final location is located in the center of the province, which is also its administrative center (Uşak City). Before 1953 , the different territories of Uşak province had been designated to the neighboring provinces of Manisa and Kütahya. Due to the introduction of a new law in that same year, the province of Uşak was founded. Uşak province currently has a total of 251 administrative offices, including 245 rural ones and 6 urban ones. 
In 2019 , the total population of the province was 370,509 -where 278,806 resided in urban areas and 91,703 resided in rural areas(TÜiK 2021). The main economic sector for urban areas is the service industry while rural areas generally rely on agriculture and animal husbandry. However, heavy industry constitutes as a major economic activity, and three organized industrial zones are located close to the district of Merkez.

\section{Materials And Methods}

A literature review was performed and criteria which are required for selecting appropriate landfill site locations were determined in accordance with the SDGs. Base maps were composed to feature the breakdown of each criterion by location; to construct and analyze the base maps ArcGIS 10.2 software was utilized. The most commonly use criteria were included in this study: roads, rivers, airports, settlements, faults, landslides, slope, geology, soil, land use capability, and land use. The map layers used in this study were projected onto WGS-1984 UTM Zone $36 \mathrm{~N}$. The cell sizes used in the analysis were $10 \times 10 \mathrm{~m}$ for all base maps and fuzzy cognitive maps.

The most common methods used in choosing potential locations for landfill sites include multi-criteria decision-making, fuzzy logic, and the analytical hierarchy process. The fuzzy logic method was employed to determine the eligible locations for landfill sites in this study. ArcGIS was applied to compose fuzzy memberships and fuzzy overlays of the criteria. The fuzzy logic tools within this software offer researchers more advantages than conventional overlay techniques when considering a combination of evidence (Gary L. Raines et al. n.d.). For example, a case study by Bahrani et al. (2016), which studied areas in ShabestarIran, presents fuzzy diagrams using MATLAB software.

The criteria maps for this study area-which were composed for landslides, faults, and other geological data -were based on previous geological studies from that region as well as maps drafted by the Directorate of Mineral Research and Exploration (MTA) (Ercan et al. 1978, 1979; Ercan and Dinçel 1980; MTA 2002). All towns, villages, and hamlets were depicted as polygons on the criteria maps. Information concerning all roads within the study area were sourced from the Uşak Zoning Plan and the OpenStreetMap database (৫) OpenStreetMap contributors 2018). Topographical maps of the study area were utilized to determine slope values. To understand the land use of the site area, Corine (CORINE Copernicus Land Monitoring Service n.d.) data along with field observations were examined and the maps were updated with these new modifications. To understand the land use capability and soil characteristics, base maps from the General Directorate of Soil \& Water of the Ministry of Rural Affairs and Cooperatives (T.C. Köyişleri ve Kooperatifleri Bakanlığı Toprak Su Genel Müdürlüğü 1979) were implemented.

The selection of a suitable location for a landfill site through the use of fuzzy logic is one of the methods that has become more widespread in recent years. In addition, the flexibility of determining criteria in this method improves site selection decisions. This flexibility provided by fuzzy logic is theoretically useful in many aspects. As pointed out by Zadeh (1965), defining the criteria for different classes of real-world objects is not fixed. For example, while members of a group within community often have many similarities, the farther a member is located from the center of that community, the more likely its similarity to the center 
will decrease. It is more probable that those members will begin to have more in common with the members of neighboring communities.

While precision is a more preferable choice in scientific research, occasionally, imprecise figures could be seen as valuable for certain types of data or the generalization of results (Zadeh 1968, p. 99). This situation has been explained in multiple studies which offer different examples about the value of imprecise figures. For instance, animals are undoubtedly different from plants and rocks; but how starfish or bacteria should be categorized can be ambiguous (Zadeh 1965). Our interpretations, views, and sentiments do not always constitute an accurate judgment of the real world. However, with Boolean logic (i.e. binary logic), values are exact and must be either true or false (Karkazi et al. 2001), these crisp situations have certainty. In other words, when it comes to binary logic, there are crisp boundaries such as 'yes' and 'no' rather than more flexible boundaries like 'a few' or 'many.' In this system, all values are classified as either belonging to a cluster or not (Zimmermann 2001). For example, a glass is either full or empty in this approach. With fuzzy logic, in contrast, the values are a continuum and therefore flexible, such as a glass being 'half full,' 'mostly full,' or 'mostly empty' (Kosko and Isaka 1993; Malczewski 1999, pp. 89-90). An item under fuzzy logic can have any degree of value between 0 and 1 ; whereas, an item under Boolean logic can only have a value of 1 or 0 (Kosko 1991, p. 264; Malczewski 1999; Weir et al. 2001). Moreover, Boolean sets have boundaries that are absolute (Hatzichristos and Potamias 2004; Karkazi et al. 2001) -a single item can only be a member of one cluster; while fuzzy sets tend to be more relative-a single item could be a member of various clusters. If a situation requires that item membership be put into a certain order, one item can also be a partial member of a previous cluster and/or a following cluster. This is represented by weak membership and strong membership values between 0 and 1 (Weir et al. 2001).

While presence and absence can be explained in binary form, as is the case for Aristotelian logic, when data is recorded for spatial analyses, there could be transitional areas amidst those spatial boundaries. For example, when considering the distribution of vegetation, there could be items or places that are considered uncertain, or fuzzy, in different cultural regions at the boarders of climate zones. Certainty and fuzziness are factors with different significance when it comes to images or maps made of raster data used for spatial analysis. In geographical studies, in particular, 'distribution' appears as transitivity rather than certainty. As noted by Malczewski, crisp and fuzzy images can be applied between two different land covers depending on the importance of certainty or transitivity of a given study (Malczewski 1999).

The use of fuzzy logic through GIS allows for map overlaying based on imprecise data and for the analysis of ambiguous cases, using simple terms (Weir et al. 2001, p. 420). In this way, the fuzzy overlay process is more convenient in situations that involve drawing errors or where certainty is not required.

The maps used for geographical analysis include numerical values and classifiable features. To analyze a landfill site location, different types of maps are overlaid onto it: maps with figures such as slope, distance, density, etc. are regarded as quantitative; while those with soil, vegetation, land use, etc. are considered qualitative (Malczewski 1999, p. 114). For quantitative maps (including roads, rivers, airports, settlements, slope, faults, and landslides) distance intervals were determined through an analysis using the Euclidean distance formula. Whereas, the degree of significance for qualitative maps (including geology, soil, land use 
capability, and land use) was assigned after a reclassification process. Based on this data, criteria maps were then composed, fuzzy memberships were created, and the most suitable landfill site location was designated for each criterion. The Fuzzy Overlay Approach (Weerasiri et al. 2014) was selected for the analysis process since it is considered a suitable method for research that concerns the selection of potential landfill site locations. Fuzzification threshold values were determined (Table 1) and fuzzy membership functions were plotted. How these membership functions theoretically work can be seen in Fig. 2. How the data from the threshold values in Table 1 and membership functions in Fig. 2 were used during the analysis process is further discussed in the results section.

\section{Results And Discussion}

\section{Assigning fuzzy membership to roads}

Any research that intends to designate a landfill site location must take into account the distance to roads. However, there seems to be a disagreement among researchers about the appropriate distance needed between a landfill site and a road network. However, establishing the ideal distance to roads is not the only issue; some researchers argue that a site with a close distance to roads is economical while others assert that keepings roads at a further distance is best due to visual pollution, odor pollution, etc. (Table 1). Based on the literature and local features, a lower-limit and upper-limit for distance is selected to be excluded, and fuzzification is then applied to allow for suitable areas to be identified. Before road distances were placed into a fuzzy overlay with ArcGIS, a linear function was used to select the close distances to be excluded and a large function was used to select the long distances to be excluded. To this end, 100 meters and below were considered unsuitable for analysis. In the analysis, firstly, large function midpoint $100 \mathrm{~m}$ and spread 5 were performed. After this stage, the linear function was referred. When performing the linear function, fuzzy membership was made by for taking maximum distance $3000 \mathrm{~m}$, for the minimum distance the longest distance on the map was selected. These fuzzy memberships were put into a fuzzy overlay analysis, and fuzzification was completed for eligible landfill sites. The analysis suggests that long-distances do not present a problem since the research area has an advanced road network; however, mountainous areas tend to present some issues. The majority of the research area was found appropriate in terms of this criterion (Fig. 3).

Assigning fuzzy membership to rivers

Distance to rivers and surface water can be considered the most crucial criterion when selecting a location for a landfill site. In the case of poor site selection, rivers and creeks could harm landfill sites, carrying the risk of percolating water leaching out of waste and into water basins. This leachate then contaminates surface waters that are intended for human consumption. The distance to rivers is one of the criterion that must be met by any research conducted on the selection of a landfill site location. The research points to various distances for consideration; these distances were all over 100 meters (Table 1). The further away from rivers, the safer it is to build a landfill site. The nearest distance that had ever been adopted in the literature was selected and a large function was applied for the analysis, with the midpoint: $200 \mathrm{~m}$ and the spread: 5 (Fig. 3). 
While it is not the case in all studies, the distance to airports is one of the criterion that must be taken into account for possible site locations that have airports within its proximity; two aspects should be considered. Firstly, organic waste from landfill sites attracts birds and large bird populations adversely affect flight safety. It is an accepted fact that large flocks of birds can pose serious issues for aircrafts around the world (George R. et al. 1971, p. 6). Secondly, landfill sites within the visual range of aircrafts that are flying at a low altitude for landing can have an adverse impact on the image of the city due to its visual pollution. Previous research studies offer distances from airports ranging from 1000 meters to 6000 meters (Table 1). The reason the distance to airports was included as a criterion in this analysis is on account of there being an airport nearly $8 \mathrm{~km}$ from the center of Uşak City. In creating this fuzzy membership, a large function was used with a midpoint: $7500 \mathrm{~m}$ and a spread: 5 (Fig. 3). In this case, all over the fields except for airport location and the surrounding lands are suitable.

Assigning fuzzy membership to settlements

The distance to settlements is another one of the most important criterion in terms of image, odor, and healthcare. Odor from landfills and treatment plants general affects a large amount of their surroundings. Additionally, waste scattered around landfills also causes problems when they are located close to settlements. The visual pollution, from landfills in close distance to settlements, also impinges upon both the view of the landscape and the image of the city (Deniz and Topuz 2018b; Işık and Çağatay 2016). Although this criterion is always taken into account in research studies, the distances that are given to rural or to urban settlements can vary. This study did not make a distinction between rural or urban settlements; thus, all settlement areas were analyzed equally. The shortest distance that was found in the literature was 800 meters (Table 1) and was used for this study. For this fuzzy membership, the large function was assigned the midpoint: $800 \mathrm{~m}$ and the spread: 5 . Since areas surrounding all types of settlement clusters were determined as inappropriate for this study, a large amount of territory was considered unsuitable (Fig. 3).

Assigning fuzzy membership to faults \& landslides

Both faults and landslides are criteria that must be incorporated into the analyses, as they can cause leachate to flow into the water and soil surrounding landfill sites. This would degrades the site even further and could possibly destroy the site through such mass movements. If such catastrophic events were to take place near or in a landfill site, the consequences would be irreversible.

(1) Faults can cause major problems for landfill sites; when tectonic movements are triggered it would allow leachate to seep through fault lines and flow into groundwater. It is important to note that landfill sites situated on a fault line is likely to be damaged by an earthquake which could lead to a major environmental disaster. For this reason, it is essential to avoid faults and ensure that a landfill site is also an adequate distance away from fault lines. The geological maps that were applied in this study were prepared by the Directorate of Mineral Research and Exploration; significant faults across the research area were then identified (MTA 2002; MTA Yer Bilimleri Portalı n.d.). It is noteworthy to mention that in the literature, any 
areas within 100 meters of a fault are excluded from analysis (Table 1). A large function with a midpoint: 100 and a spread: 5 was assigned. (2) Fossil and active landslides are areas where mass movements have occurred in the past or are still actively occurring; these types of areas were identified and digitalized on maps prepared by the Directorate of Mineral Research and Exploration (MTA 2002; MTA Yer Bilimleri Portalı n.d.), determined unsuitable for this analysis, and excluded from the study. The literature suggests that a distance of 600 meters or more is considered suitable (Table 1). For this analysis, the large function was given a midpoint: $600 \mathrm{~m}$ and a spread: 5 . The analysis indicated, that the central part of the Uşak province, in particular, is the most suitable for landfill site locations in terms of faults; whereas, for landslides, the northern boarders were found most suitable.

Assigning fuzzy membership to slope

When selecting a landfill site location, it is most logical to choose a low degree of slope over a high degree of slop-in order to help prevent leakage or leachate. Low-sloped sites have a reduced risk of flooding since they have a slower flow rate of water. In addition, construction costs and equipment tend to be less expensive for such sites. According to the literature, areas with a slope of $0^{\circ}$ to $15^{\circ}$ are considered suitable locations for landfill sites (Table 1). In this study, areas with a slope of up to $10^{\circ}$ were selected as suitable locations. In this analysis, the small fuzzy function was employed with a midpoint: $5^{\circ}$ and a spread: 5 . The analysis indicated that the flatlands in the southern section of the study area, in particular, is a suitable location for landfill sites in terms of slope. The stream beds and mountainous regions with high degrees of slope scored fuzzy values of 0 or near 0 , in the fuzzy overlay process (Fig. 3).

When considering the location of a landfill site, it is important to understanding the geological formations and the permeability capacity of the area. While modern techniques allow for the insulation of landfill floors by means of various materials, geological characteristics are still relevant. Unfractured crystalline rock is known to be the best type of bedrock for landfill sites because of their low permeability capacity. Aside from unfractured crystalline, shale, and clay are also accepted as physically suitable locations for landfill sites. The low permeability of these bedrock types make them more advantageous than other rock types because of the reduced potential for ground and surface water pollution by leachate into agricultural lands. However, sandstone and unconsolidated sand/gravel, are not preferred due to their high permeability which allows water to quickly pass to lower layers, thus, causing pollution (Şener 2004). Therefore, unsuitable rocks such as limestone have been excluded from some analyses (Sadek et al. 2006, p. 76; Oweis ve Khera, 1990 as cited in Şener 2004; Stemn and Kumi-Boateng 2019, pp. 727-728). Oweis and Khera (as cited in Şener 2004), ranked rock types from very high suitability (unfractured crystalline rock) to unsuitable (unconsolidated sand/gravel) (Table 2).

The Menderes Massif basin is a large area situated in western Anatolia and geologically consists of metamorphic rock; the area of study is located on the edges of this basin. The bedrock of this area is mainly comprised of unfractured crystalline of the Precambrian age. In addition, for landfill sites, the formation of clayey calcareous deposits as well as the growth of quaternary alluvial deposits and detrital cones, from the Neogene age, allows different geological characteristics to exist in the same area. 
The 13 geological formations in the study area were mapped and reclassified from the most-suitable areas (having a value of 10) to the least-suitable areas (having a value of 0 ) for landfill site locations. After this process, fuzzy overlay was employed. The Eşme Formation and Musadağı Marbles both scored a 10, due to their crystalline and marble constitutions, with no discontinuity. While the Ulubey Formation, the Asartepe Formation, and the Fossil and Actual Alluvial \& Alluvial Fans were then excluded since they all scored a 0 , due to their lime or tuffite constitutions which have high permeability. The Yeniköy Formation, the Küçükderbent Formation, and the Ahmetler Formation all received a score of 1 (less suitable for a landfill site) as a result of their high permeability. All other formations scored intermediate values in accordance with their physical characteristics.

The geological map, which is a qualitative criteria map, was analyzed with the liner function; the minimum value of 1 and the maximum value of 10 was designated (Table 3 ). The results suggest that the district of Eşme, the district of Banaz, and the northern parts of the Merkez district are the most eligible locations for a landfill site (Fig. 3).

Assigning fuzzy membership to soil

To determine a location for a landfill site, soil type is important in two aspects: to avoid damage to natural resources and to decrease the harm to the environment from waste. First of all, when fertile soil of agricultural quality is used for non-agricultural purposes, this has an adverse impact on the food supply chain for the global population as well as on agricultural production. For sustainability purposes, fertile agricultural lands should not be lost. That is why non-alluvial soil that has low agricultural value and insufficient mineral composition is the most suitable land to serve as a landfill site. In addition, high amounts of clay in soil is of importance for location selection: clay levels are natural layers that prevent leachate from flowing into groundwater. Since the clay ratio was taken into account in the fuzzy membership for geology, only the agricultural importance of the soil was incorporated into the fuzzification process for this criterion. Soil classes have been analyzed in past research through various ways such as its content, texture, etc. (Table 1). It can be seen that geological and soil characteristics had also been taken into account and some areas had been restricted and excluded from those analyses (Sadek et al. 2006, p. 76; Stemn and Kumi-Boateng 2019, pp. 727-728). Fertile soils and sandy soils with high permeability are scored with a low value while highly-clayed soils unfit for agriculture are considered suitable and scored a high value. In this study, alluvial plains were considered unsuitable while colluvial soils were regarded as less suitable due to its permeability. High mountainous grasslands and rendzina soils were selected as the most suitable lands and were reclassified with a value of 10 . A linear function was used with the minimum value of 0 and the maximum of 10 . The fuzzy membership result determined that the plains of Uşak, Banaz, and Sivasli; the alluvial deposits of the Banaz and Gediz streams; and the agricultural lands in Eşme are all unsuitable (Fig. 3).

Assigning fuzzy membership to land use capability

Land use capability is one of the criterion to be taken into account for landfill site selection. Even if its natural and economic capacity is not fully utilized at the present moment, considering the potential of a location may allow the land to be used more rationally in the future. Therefore, lands with possible 
agricultural value were selected from studies commissioned by various ministerial departments of Turkey (T.C. Başbakanlık Köy Hizmetleri Genel Müdürlüğü 1997; T.C. Köyişleri ve Kooperatifleri Bakanlığı Toprak Su Genel Müdürlüğü 1979) and land use capability maps were then drafted. The research area contains lands ranging from first class (I) - which are best for cultivation, to eighth class (VIII)-which has no agricultural potential. After reclassification, new values were given to land use capability classes. Both first $(I)$ and second (II) land classes were considered exclusive areas in previous research; these same classes were selected and excluded as possible landfill site locations for this study (Table 1). When creating the fuzzy membership, first and second land classes were excluded, third and fourth land classes were scored with a low value, and all other land classes were assigned a score of 10. A linear function was chosen, with 5 assigned to the minimum value and 10 to the maximum value. As a result of the fuzzy membership procedure, it was found that the central part of the study area-particularly, the districts of Banaz and Merkez-are unsuitable due to their agricultural lands which have irrigation capabilities thanks to rivers in those districts (Fig. 3).

Assigning fuzzy membership to land use

Land use is another important criterion in the selection of a landfill site location. In this selection process, it is imperative to exclude lands that have a high potential for use: areas that are already generating good revenue or are capable of being used for important purposes. Designating which areas are suitable and which areas are unsuitable should be mapped. For this purpose, the land cover maps drafted as a part of the Corine Project (CORINE Copernicus Land Monitoring Service n.d.) were utilized; any incorrect or incomplete data on these maps were updated. These amended maps were reclassified according to the level of suitability of the land, from 0 to 10 . While it has been argued that landfill sites can be built on agricultural lands if needed (Lunkapis n.d., p. 153); usually in the research, urban areas, agricultural lands, and natural forests are regarded as areas where landfill sites should not be built (Karkazi et al. 2001; Lunkapis n.d.; Stemn and Kumi-Boateng 2019; Chabuk et al. 2016a; Sadek et al. 2006). For this reason, continuous and discontinuous urban fabric, industrial or commercial units, airports, mineral extraction sites, construction sites, vineyards, annual crops associated with permanent crops, complex cultivation patterns, and estuaries and water bodies were excluded from this analysis. While digitizing the reclassified the raster maps, a score of 1 was given to orchards and berry plantations, beaches, dunes, and sands; a score of 4 was given to permanently irrigated lands, broad-leaved forests, coniferous forests, and mixed forests; and a score of 8 was given to non-irrigated, arable lands. Whereas, a score of 9 was given to pastures, lands principally occupied by agriculture, and land with significant areas of natural vegetation and a score of 10 was given to other types of land covers such as natural grasslands, transitional woodlands-shrubs, sclerophyllous vegetation, bare rocks, and areas which are sparsely vegetated. A linear function was used for the fuzzy membership with the minimum value of 1 , and the maximum value of 10 (Table 1).

Fuzzy overlay and evaluating

As a result of the fuzzy overlay performed on the fuzzy membership maps of criteria which are displayed in Fig. 3, a map of the most optimum locations for landfill sites was produced and can be seen in Fig. 4. The total size of the study area is 554,608 hectares. Out of the areas with values ranging from 0 to 1 after the 
fuzzy overlay, the lands with a score of 0.75 and above were designated as the most suitable. The total size of this eligible land is nearly 2,039 hectares. The total size of the land that could be a secondary option, if the aforementioned areas were deemed unfit or unusable, is nearly 22,130 hectares. While the ratio of the most suitable land to the total study area is below $1 \%$, the ratio of land that could be considered as a secondary option is around $4 \%$. Based on the parameters in the criteria maps that were analyzed, rivers, landslide sites, settlements, and areas which could never serve as landfill sites has a total area of 23,190 hectares; the ratio of this are to the total area is $4.2 \%$. This analysis revealed that the most optimal locations to serve as a landfill site are primarily located within the territory of the Eşme district in the southwestern part of the research area (Fig. 4). The flatlands of the Karahallı district and the land near the western border of the Merkez District were also considered suitable for landfill site locations. The lands in the western border of the Merkez District have been identified as suitable places in various studies conducted with different methods(Deniz and Topuz 2018a).

\section{Conclusion}

The purpose of this research was to find the most suitable landfill site locations within the province of Uşak in the western part of Turkey. A literature review was conducted to determine the most important criteria in the selection of landfill site locations. Criteria maps were created by digitizing the base maps and field research findings. GIS software was used to draw the maps. By creating fuzzy memberships from these maps, the most suitable site for each criterion was determined and the selection of the most optimal locations were identified through a fuzzy overlay.

The threshold values, used for the fuzzy logic of this study, were selected from the strictest values found in the literature. For this reason, as a result of the analysis using fuzzy logic, the most precise results have emerged. If deemed necessary, other analyses could be performed with more flexible threshold values, based on the literature and field studies. In this case, the total size of land that could serve as landfill site locations would also increase. If there is an urgent need regarding a landfill site location, and there are not many opportunities available, in order to increase the acreage of potential land, a more flexible analysis could be performed. For instance, some agricultural lands had been included in previous studies conducted in Turkey.

As a result of this analysis, the most eligible lands were identified while taking into consideration all provincial boarders. In this study, the most optimal locations for landfill sites are situated within the borders of the Eşme district. In addition, some suitable sites in the Merkez district were also identified. If it is found necessary, large-scale treatment plants could be built in these selected areas to run a more efficient, costeffective, and environmentally friendly waste management operation. Developments in the recycling industry have been able to make nearly all resources reusable. This transforms a large amount of previously unused and eliminated waste into reusable resources. For locations that were selected as suitable, treatment plants, recycling facilities, and energy generation facilities could be build next to the landfill sites. In such a case, this will help waste management become integrated, offer a solution to many environmental problems at the local level, and consume previously-unused waste for energy production. However, the 
criteria for these purposes were not analyzed in this study as its intention was solely intended to determine a landfill site location.

When combating a waste problem, although the most important issue is to produce less waste material, the most problematic issue is how to collect and store that waste once it has been created. Since this is the final step in the waste management process and there is an abundance of unwanted waste which needs to be controlled, the amount of research on the subject of landfills continues to grow.

\section{Declarations}

Funding: This research received no external funding.

Conflicts of Interest: The author(s) declare no conflict of interest.

Availability of data and material (data transparency): The datasets generated during and/or analysed during the current study are available from the corresponding author on reasonable request.

Code availability: Not applicable

Ethics approval: Not applicable

Consent for publication: Not applicable

\section{Acknowledgments}

This work is not funded by any foundation. The analyzes applied in the research were made in the Uşak University Geographical Information Systems Laboratory.

\section{References}

1. (c) OpenStreetMap contributors. (2018, January 22). OpenStreetMap katılımcıları OpenStreetMap turkeylatest-free.shp.zip. OpenStreetMap. https://download.geofabrik.de/europe/turkey.html\#. Accessed 23 January 2018

2. Adewumi, J. R., Ejeh, O. J., Lasisi, K. H., \& Ajibade, F. O. (2019). A GIS-AHP-based approach in siting MSW landfills in Lokoja, Nigeria. SN Applied Sciences, 1(12), 1528. https://doi.org/10.1007/s42452019-1500-6

3. Aksoy, E. (2016). Uzaktan algılama ve Coğrafı Bilgi Sistemleri kullanılarak Antalya ili katı atık deponi alanı belirlenmesi (Yüksek Lisans). The Graduate School of Natural And Applied Sciences of Akdeniz University, Antalya. Retrieved from http://acikerisim.akdeniz.edu.tr/xmlui/handle/123456789/2847

4. Azapagic, A., \& Perdan, S. (2000). Indicators of Sustainable Development for Industry: A General Framework. Process Safety and Environmental Protection, 78(4), 243-261.

https://doi.org/10.1205/095758200530763 
5. Bahçeci, İ. (2006). Katı atık deponi yeri seçiminde coğrafı bilgi sistemlerinin kullanımı: Side-Manavgat turizm bölgesi örneği (Yüksek Lisans). Akdeniz Üniversitesi Fenbilimleri Enstitüsü.

6. Bahrani, S., Ebadi, T., Ehsani, H., Yousefi, H., \& Maknoon, R. (2016). Modeling landfill site selection by multi-criteria decision making and fuzzy functions in GIS, case study: Shabestar, Iran. Environmental Earth Sciences, 75(4), 337. https://doi.org/10.1007/s12665-015-5146-4

7. Chabuk, A., Al-Ansari, N., Hussain, H. M., Knutsson, S., \& Pusch, R. (2016a). Landfill Siting Using GIS and AHP (Analytical Hierarchy Process): A Case Study Al-Qasim Qadhaa, Babylon, Iraq. Journal of Civil Engineering and Architecture, 10, 530-543. https://doi.org/10.17265/1934-7359/2016.05.002

8. Chabuk, A., Al-Ansari, N., Hussain, H. M., Knutsson, S., \& Pusch, R. (2016b). Landfill site selection using geographic information system and analytical hierarchy process: A case study Al-Hillah Qadhaa, Babylon, Iraq. Waste Management \& Research, 34(5), 427-437. https://doi.org/10.1177/0734242X16633778

9. CORINE Copernicus Land Monitoring Service. (n.d.). CLC 2018 - Copernicus Land Monitoring Service. Land item. https://land.copernicus.eu/pan-european/corine-land-cover/clc2018. Accessed 23 January 2018

10. Coşkuner, G. (1996). Sivas kenti için alternatif katı atık deponi alanının seçilmesi ve projelendirilmesi (Yüksek Lisans). Cumhuriyet Üniversitesi Fen Bilimleri Enstitüsü.

11. Dağıstanlıoğlu, C. (2012). Eğirdir katı atık deponi alanının yer seçimi kriterlerinin coğrafı bilgi sistemleri (CBS) ile belirlenmesi (Doktora Tezi). Ege Üniversitesi Fen Bilimleri Enstitüsü.

12. Deniz, M., \& Topuz, M. (2018a). Coğrafı Bilgi Sistemleri (CBS) Destekli Çok Kriterli Karar Verme Yöntemleri ve Analitik Hiyerarşi Tekniği Kullanarak Uşak Merkez iliçede Alternatif Çöplük Alanlarının Belirlenmesi. Journal of History Culture and Art Research, 7(5), 544-578.

13. Deniz, M., \& Topuz, M. (2018b). Uşak illinde Mevcut ve Eski Atık Depolama (Deponi) Alanlarının ve Atık Su Arıtma Tesislerinin Koku Kirliliği Açısından Etkilerinin Coğrafı Bilgi Sistemleri ile Analizi. In III. International Research Congress on Social Sciences 05-08 September 2018 Skopje (pp. 511-518). Presented at the III. Uluslararası Sosyal BilimlerAraştırmaları Kongresi 05 - 08 Eylül 2018 Uluslararası Balkan Üniversitesi Üsküp, Ankara: Anadolu Kültürel Araştırmalar Dergisi (ANKAD) Yayınları.

14. Despotakis, V. K., \& Economopoulos, A. P. (2007). A GIS model for landfill sitting. Global NEST Journal, 9(1), 29-34. https://doi.org/10.30955/gnj.000441

15. Effat, H. A., \& Hegazy, M. N. (2012). Mapping potential landfill sites for North Sinai cities using spatial multicriteria evaluation. The Egyptian Journal of Remote Sensing and Space Science, 15(2), 125-133. https://doi.org/10.1016/j.ejrs.2012.09.002

16. Egger, S. (2006). Determining a sustainable city model. Integrative Modelling of Climatic, Terrestrial and Fluvial Systems, 21(9), 1235-1246. https://doi.org/10.1016/j.envsoft.2005.04.012

17. El Alfy, Z., Elhadary, R., \& Elashry, A. (2010). Integrating GIS and MCDM to deal with landfill site selection. International Journal of Engineering \& Technology IJET-IJENS, 10(6), 33-42. http://www.ijens.org/103106-7474\%20IJET-IJENS.pdf

18. Ercan, T., \& Dinçel, A. (1980). 1:50.000 Ölçekli Uşak-K22-c Jeoloji Haritası. 1:50.000 Ölçekli Jeoloji Haritası, Ankara: MTA. 
19. Ercan, T., Dinçel, A., \& Günay, E. (1979). Uşak Volkanitlerinin Petrolojisi ve Plaka Tektoniği Açısından Ege Bölgesindeki Yeri. Türkiye Jeoloji Kurumu Bülteni, 22, 185-198. http://www.jmo.org.tr/resimler/ekler/1108a3dbfe4636c_ek.pdf?dergi...

20. Ercan, T., Dinçel, A., Metîn, S., Türkecan, A., \& Günay, E. (1978). Uşak Yöresindeki Neojen Havzalarının Jeolojisi. Uşak Yöresindeki Neojen Havzalarının Jeolojisi, 21(2), 97-115.

http://www.jmo.org.tr/resimler/ekler/bc7d9c600d61c08_ek.pdf?

dergi=T\%DCRK\%DDYE\%20JEOLOJ\%DD\%20B...

21. Erdoğan, B. B. (2019). Coğrafı bilgi sistemleri ile katı atık düzenli depolama tesisi yer seçimi (Yüksek Lisans). Ondokuz Mayıs Üniversitesi Fen Bilimleri Enstitüsü Harita Mühendisliği Anabilim Dalı.

22. Ersoy, H. (2007). Trabzon Illi Katı Atıkları Için Düzenli Depolama Yeri Seçimi ve Önerilen Düzyurt Düzenli Depolama Alanının Mühendislik Jeolojisi Açısından Incelenmesi (DoktoraTezi). Karadeniz Teknik Üniversitesi Fen Bilimleri Enstitüsü, Jeoloji Mühendisliği Ana Bilim Dalı, Trabzon.

23. Ersoy, H., \& Bulut, F. (2009). Spatial and multi-criteria decision analysis-based methodology for landfill site selection in growing urban regions. Waste Management \& Research, 27(5), 489-500. https://doi.org/10.1177/0734242X08098430

24. García-Feijoo, M., Eizaguirre, A., \& Rica-Aspiunza, A. (2020). Systematic Review of SustainableDevelopment-Goal Deployment in Business Schools. Sustainability, 12(1). https://doi.org/10.3390/su12010440

25. Gary L. Raines, Don L. Sawatzky, \& Graeme F. Bonham-Carter. (n.d.). Incorporating Expert Knowledge New fuzzy logic tools in ArcGIS 10. https://www.esri.com/news/arcuser/0410/files/fuzzylogic.pdf. Accessed 15 June 2019

26. George R., D., JR, Truett V., D., JR., Thomas J., S., \& Robert M., C. (1971). Land Disposal Sites Near Airports Reporting Bird/Aircraft Hazards: A Survey for the Inter-Agency Bird Hazard Committee (No. A Division of Technical Operations Open-Fiel Report (TSR 1.6.004/0)). United States Environmental Protection Agency Solide Waste Management Office.

27. Gorsevski, P. V., Donevska, K. R., Mitrovski, C. D., \& Frizado, J. P. (2012). Integrating multi-criteria evaluation techniques with geographic information systems for landfill site selection: A case study using ordered weighted average. Waste Management, 32(2), 287-296. https://doi.org/10.1016/j.wasman.2011.09.023

28. Güler, D. (2016). Analitik Hiyerarşi Yöntemi Ve Coğrafı Bilgi Sistemleri Ile Alternatif Katı Atık Düzenli depolama Alanı Yer Seçimi: İstanbul Illi Örneği (Yüksek Lisans). İstanbul Teknik Üniversitesi Fen Bilimleri Enstitüsü, İstanbul.

29. Harita Genel Müdürlüğü. (2020, February 5). İl ve İlçe Yüz ölçümleri. https://www.harita.gov.tr/images/urun/il_ilce_alanlari.pdf. Accessed 5 February 2020

30. Hatzichristos, T., \& Potamias, J. (2004). Defuzzification Operators For Geographical Data Of Nominal Scale. In Geoinformatics 2004 Proc. 12th Int. Conf. on Geoinformatics - Geospatial Information Research: Bridging the Pacific and Atlantic University of Gävle, Sweden, 7-9 June 2004 (pp. 481-488). Presented at the Geoinformatics 2004 Proc. 12th Int. Conf. on Geoinformatics - Geospatial Information 
Research: Bridging the Pacific and Atlantic University of Gävle, Sweden, 7-9 June 2004, Gävle, Sweden. http://giscience.hig.se/binjiang/geoinformatics/files/p481.pdf. Accessed 8 March 2020

31. Işık, F., \& Çağatay, U. (2016). Çöp depolama ve arıtma tesislerinin etki alanının coğrafı bilgi sistemi tabanlı olarak belirlenmesi: Manisa örneği. Paradoks Ekonomi, Sosyoloji ve Politika Dergisi, 12(1), 6887.

32. İşlek, Ş. (2004). Cizre'de katı atık yönetimi ve deponi yer seçimi (Yüksek Lisans). Harran Üniversitesi Fen Bilimleri Enstitüsü Çevre Mühendisliği Anabilim Dalı, Şanlıurfa.

33. Kao, J.-J., \& Lin, H.-Y. (1996). Multifactor spatial analysis for landfill siting. Journal of environmental Engineering, 122(10), 902-908.

34. Kaplan, F. A. (2002). Gaziantep kenti için katı atık deponi alanının seçilmesi ve projelendirilmesi (Yüksek Lisans). Cumhuriyet Üniversitesi Fen Bilimleri Enstitüsü, Gaziantep.

35. Kaplan Mintz, K., \& Kurman, J. (2020). A cross-cultural perspective on facilitators of recycling. Environment, Development and Sustainability, 22(7), 6627-6643. https://doi.org/10.1007/s10668-01900503-4

36. Kara, C., \& Doratli, N. (2012). Application of GIS/AHP in siting sanitary landfill: a case study in Northern Cyprus. Waste Management \& Research, 30(9), 966-980. https://doi.org/10.1177/0734242X12453975

37. Karayılan, S. (2018). Modelling and assessment of landfill gas generation at Afyonkarahisar landfill site (Yüksek Lisans). The Graduate School of Natural And Applied Sciences of Middle East Technical University, Ankara.

38. Karkazi, A., Hatzichristos, T., Mavropoulos, A., Emmanouilidou, B., \& Elseoud, A. (2001). Landfill siting using GIS and fuzzy logic. Presented at the Eight International Waste Management\&Landfill Symposium, Sardinya, Sardinya. www.epem.gr/pdfs/2001_2.pdf. Accessed 14 June 2019

39. Kavaklı, F. (2011). İzmir ili Harmandalı çöp deponi alanı örneğinde kentlerin katı atık depolama alan seçim ve kullanım ilkelerinin irdelenmesi üzerine bir araştırma (Yüksek Lisans). Ege Üniversitesi Fen Bilimleri Enstitüsü.

40. Klitgaard, K. (2020). Sustainability as an Economic Issue: A BioPhysical Economic Perspective. Sustainability, 12(1). https://doi.org/10.3390/su12010364

41. Kolay, U. E. (2012). Alternatif katı atık deponi alanlarının yer seçiminde coğrafı bilgi sistemi tabanlı örnek bir uygulama (Yüksek Lisans). Bahçeşehir Üniversitesi Fen Bilimleri Enstitüsü / Kentsel Sistemler ve Ulaştırma Yönetimi Anabilim Dalı, İstanbul.

42. Kontos, T. D., Komilis, D. P., \& Halvadakis, C. P. (2005). Siting MSW landfills with a spatial multiple criteria analysis methodology. Waste Management, 25(8), 818-832. https://doi.org/10.1016/j.wasman.2005.04.002

43. Kosko, B. (1991). Neural networks and fuzzy systems: adynamical systems approach to machine intelligence. Englewood Cliffs, New Jersey: Prentice Hall.

44. Kosko, B., \& Isaka, S. (1993). Fuzzy Logic. Scientific American, 269(1), 76-81. www.jstor.org/stable/24941550. Accessed 8 March 2020 
45. Krajnc, D., \& Glavič, P. (2003). Indicators of sustainable production. Clean Technologies and Environmental Policy, 5(3), 279-288. https://doi.org/10.1007/s10098-003-0221-z

46. Küçükönder, M., \& Karabulut, M. (2007). Çok Kriterli Analiz Yöntemi Kullanılarak Kahramanmaras’ta Çöp Depolama Alanı Tespiti. Coğrafı Bilimler Dergisi, 5(2), 55-76. https://doi.org/10.1501/Cogbil_0000000075

47. Łozowicka, A. (2020). Evaluation of the Efficiency of Sustainable Development Policy Implementation in Selected EU Member States Using DEA. The Ecological Dimension. Sustainability, 12(1). https://doi.org/10.3390/su12010435

48. Lunkapis, G. J. (n.d.). GIS as Decision Support Tool for Landfills Siting. https://www.geospatialworld.net/article/gis-as-decision-support-tool-for-landfills-siting/. Accessed 19 February 2020

49. Malczewski, J. (1999). GIS and multicriteria decision analysis. USA: John Wiley \& Sons.

50. Modibbo, U. M., Ali, I., \& Ahmed, A. (2020). Multi-objective optimization modelling for analysing sustainable development goals of Nigeria: Agenda 2030. Environment, Development and Sustainability. https://doi.org/10.1007/s10668-020-01022-3

51. MTA. (2002). 1:500.000 Ölçekli Jeoloji Haritası İzmir Paftası. Jeoloji Haritası, Ankara: MTA.

52. MTA Yer Bilimleri Portalı. (n.d.). Yerbilimleri Harita Görüntüleyici ve Çizim Editörü. http://yerbilimleri.mta.gov.tr/anasayfa.aspx. Accessed 5 March 2018

53. Nas, B., Cay, T., Iscan, F., \& Berktay, A. (2009). Selection of MSW landfill site for Konya, Turkey using GIS and multi-criteria evaluation. Environmental Monitoring and Assessment, 160(1), 491. https://doi.org/10.1007/s10661-008-0713-8

54. Öner, G. (2019). Landfill site selection and landfill liner design for Polatli, Ankara (Yüksek Lisans). The Graduate School Of Natural And Applied Sciences of Middle East Technical University.

55. Özdemir Kipel, B. (2017). Bulanık Mantık Kullanarak Katı Atık Depolama Tesisi lçin En Uygun Konum Belirleme (Yüksek Lisans). Ankara Üniversitesi Fen Bilimleri Enstitüsü.

56. Rodić, L., \& Wilson, C. D. (2017). Resolving Governance Issues to Achieve Priority Sustainable Development Goals Related to Solid Waste Management in Developing Countries. Sustainability, 9(3), 404. https://doi.org/10.3390/su9030404

57. Rosenberg, A. A., Fogarty, M. J., Sissenwine, M. P., Beddington, J. R., \& Shepherd, J. G. (1993). Achieving Sustainable Use of Renewable Resources. Science, 262(5135), 828829.

https://doi.org/10.1126/science.262.5135.828

58. Sadek, S., El-Fadel, M., \& Freiha, F. (2006). Compliance factors within a GIS-based framework for landfill siting. International Journal of Environmental Studies, 63(1), 71-86.

https://doi.org/10.1080/00207230600562213

59. Şener, B. (2004). Landfill site selection by using geographical information systems (Yüksek Lisans). The Graduate School of Natural And Applied Sciences of Middle East Technical University, Ankara.

60. Şener, B., Süzen, M. L., \& Doyuran, V. (2006). Landfill site selection by using geographic information systems. Environmental Geology, 49(3), 376-388. https://doi.org/10.1007/s00254-005-0075-2 
61. Siddiqui, M. Z., Everett Jess W., \& Vieux Baxter E. (1996). Landfill Siting Using Geographic Information Systems: A Demonstration. Journal of Environmental Engineering, 122(6), 515-523. https://doi.org/10.1061/(ASCE)0733-9372(1996)122:6(515)

62. Stemn, E., \& Kumi-Boateng, B. (2019). Hazardous waste landfill site selection in Western Ghana: An integration of multi-criteria decision analysis and geographic information system. Waste Management \& Research, 37(7), 723-736. https://doi.org/10.1177/0734242X19854530

63. Sumathi, V. R., Natesan, U., \& Sarkar, C. (2008). GIS-based approach for optimized siting of municipal solid waste landfill. Waste Management, 28(11), 2146-2160.

https://doi.org/10.1016/j.wasman.2007.09.032

64. Sustainable Development Knowledge Platform. (n.d.). https://sustainabledevelopment.un.org/sdgs. Accessed 15 February 2020

65. T.C. Başbakanlık Köy Hizmetleri Genel Müdürlüğü. (1997). Uşak Ili Arazi Varlığı. Ankara: T.C. Başbakanlık Köy Hizmetleri Genel Müdürlüğü Etüd ve Proje Dairesi Başkanlığı.

66. T.C. Köyişleri ve Kooperatifleri Bakanlığı Toprak Su Genel Müdürlüğü. (1979). Uşak İli Toprak ve Su Kaynakları Kullanımı Planlaması. Toprak Edütleri ve Hariatalama Daire Başkanlığı.

67. Tchobanoglous, G., Kreith, F., \& Williams, M. E. (2002). Chapter 1 Introduction. In G. Tchobanoglous \& Frank Kreith (Eds.), Handbook of Solid Waste Management (Second Edition., p. 1.1-1.27). New York Chicago San Francisco Lisbon London Madrid Mexico City Milan New Delhi San Juan Seoul Singapore Sydney Toronto: McGRAW-HILL.

68. TÜiK. (2021, April 3). Adrese Dayalı Nüfus Kayıt Sonuçları. Adrese Dayalı Nüfus Kayıt Sonuçları. https://biruni.tuik.gov.tr. Accessed 3 April 2021

69. United Nations. (n.d.). https://www.un.org/sustainabledevelopment/. https://www.un.org/sustainabledevelopment/. Accessed 25 March 2020

70. Veleva, V, Hart, M., Greiner, T., \& Crumbley, C. (2001). Indicators of sustainable production. Journal of Cleaner Production, 9(5), 447-452. https://doi.org/10.1016/S0959-6526(01)00004-X

71. Veleva, Vesela, \& Ellenbecker, M. (2001). Indicators of sustainable production: framework and methodology. Journal of cleaner production, 9(6), 519-549.

72. Waste management. (n.d.). https://sustainabledevelopment.un.org/dsd_aofw_ni/ni_pdfs/NationalReports/south_africa/Waste.pdf. Accessed 18 February 2020

73. Weerasiri, T., Wirojanagud, W., \& Srisatit, T. (2014). Assessment of Potential Location of High Arsenic Contamination Using Fuzzy Overlay and Spatial Anisotropy Approach in Iron Mine Surrounding Area. The Scientific World Journal, 2014, 905362. https://doi.org/10.1155/2014/905362

74. Weir, M. J. C., Kainz, W., \& Radwan, M. M. (2001). Data quality and metadata. In R. A. de By (Ed.), Principles of geographic information systems: an introductory textbook (2nd ed., pp. 399-462). Enschede, The Netherlands: International Institute for Aerospace Survey and Earth Sciences. https://www.academia.edu/26284460/Principles_GIS_Rolf_de_By

75. Yildirim, V. (2012). Application of raster-based GIS techniques in the siting of landfills in Trabzon Province, Turkey: a case study. Waste Management \& Research, 30(9), 949-960. 
https://doi.org/10.1177/0734242X12445656

76. Yousefi, H., Javadzadeh, Z., Noorollahi, Y., \& Yousefi-Sahzabi, A. (2018). Landfill Site Selection Using a Multi-Criteria Decision-Making Method: A Case Study of the Salafcheghan Special Economic Zone, Iran. Sustainability, 10(4), 1107. https://doi.org/10.3390/su10041107

77. Zadeh, L. A. (1965). Fuzzy sets. Information and Control, 8(3), 338-353. https://doi.org/10.1016/S0019-9958(65)90241-X

78. Zadeh, L. A. (1968). Fuzzy algorithms. Information and Control, 12(2), 94-102. https://doi.org/10.1016/S0019-9958(68)90211-8

79. Zhu, Y., Zhang, Y., Luo, D., Chong, Z., Li, E., \& Kong, X. (2020). A review of municipal solid waste in China: characteristics, compositions, influential factors and treatment technologies. Environment, Development and Sustainability. https://doi.org/10.1007/s10668-020-00959-9

80. Zimmermann, H.-J. (2001). Fuzzy set theory-and its applications. (4th ed.). Newyork: Springer Science \& Business Media, LLC.

\section{Tables}


Table 1. Criteria and suggested features for landfilling

Unsuitable or low suitable Criteria

Settlements

(m)

$\leq 200-210$ (Adewumi et al. 2019; Sumathi et

al. 2008); $\leq 500$ (Despotakis and

Economopoulos 2007; Gorsevski et al. 2012;

Sadek et al. 2006); $\leq 1000$ (Kara and Doratli

2012; Karkazi et al. 2001; Küçükönder and

Karabulut 2007; Yousefi et al. 2018)

Rivers (m)

$\leq 100$ (Lunkapis n.d.); 100 (Küçükönder and Karabulut 2007); $\leq 240$ (Kao and Lin 1996); $\leq 300$ (Despotakis and Economopoulos 2007); $\leq 500$ (Kontos et al. 2005; Yildirim 2012); 500-510 (Adewumi et al. 2019); $\leq 800$ (Karkazi et al. 2001); $\leq 1000$ (Chabuk et al. 2016b; Kara and Doratli 2012; Stemn and Kumi-Boateng 2019).

Faults (m) $\quad \leq 100$ (Despotakis and Economopoulos 2007; Küçükönder and Karabulut 2007); $\leq 200$ (Yildirim 2012; Yousefi et al. 2018)(9,11); $\leq 500$ (Gorsevski et al. 2012; Sadek et al. 2006); $\leq 800$ (Karkazi et al. 2001); $\leq 1000$ (Güler 2016)

Airport (m) $\leq 1000$ (Güler 2016); $\leq 4500$ (Karkazi et al. 2001); 3000 (Despotakis and Economopoulos 2007); $\leq 6000$ (Stemn and Kumi-Boateng 2019); $\leq 1500-3000$ (Sadek et al. 2006)

Roads (m)
Suitable Criteria

$\geq 800$ (Gorsevski et al. 2012); $\geq 2000$

(Karkazi et al. 2001); $\geq 3000$

(Küçükönder and Karabulut 2007; Lunkapis n.d.; Yousefi et al. 2018); $\geq 5000$ (Adewumi et al. 2019); $\geq 10000$

(Stemn and Kumi-Boateng 2019; Sumathi et al. 2008)

600 (Adewumi et al. 2019; Kao and Lin 1996); 1200 (Karkazi et al. 2001); 3000 (Chabuk et al. 2016a; Küçükönder and Karabulut 2007; Yildirim 2012); 4000 (Stemn and Kumi-Boateng 2019)
1000 (Gorsevski et al. 2012; Yildirim 2012; Yousefi et al. 2018); 1200 (Karkazi et al. 2001); 2000 (Sadek et al. 2006); 3000 (Küçükönder and Karabulut 2007); 4000 (Stemn and Kumi-Boateng 2019)

$\geq 7000$ (Güler 2016); $\geq 7500$ (Karkazi et al. 2001) $\leq 100$ (Despotakis and Economopoulos 2007; Küçükönder and Karabulut 2007); 0-500 (Chabuk et al. 2016a); >1000 (Adewumi et al. 2019; El Alfy et al. 2010; Kao and Lin 1996); $\leq 3000$ (Chabuk et al. 2016a); >5000 (Yildirim 2012); 300-600 (Sadek et al. 2006); $\geq 100$ (Lunkapis n.d.)

Landslide $\quad \leq 600$ (Küçükönder and Karabulut 2007)

(m)

Slope (0)

$>15$ (Kontos et al. 2005; Nas et al. 2009); >20 (Deniz and Topuz 2018a; Kara and Doratli 2012; Sadek et al. 2006; Stemn and KumiBoateng 2019); >25 (Yildirim 2012); >30 (Gorsevski et al. 2012)

$\leq 80$ (Kao and Lin 1996); 200-215

(Adewumi et al. 2019) <500 (Yildirim 2012); 1000-1250 (Küçükönder and Karabulut 2007); 1000-2000 (Chabuk et al. 2016a); 600-2000 (Sadek et al. 2006)

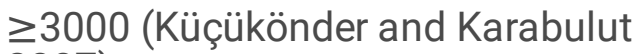
2007)

0-50 (Effat and Hegazy 2012; Chabuk et al. 2016a, 2016b; Ersoy and Bulut 2009; Kara and Doratli 2012; Küçükönder and Karabulut 2007; Sadek et al. 2006; Şener 2004; Stemn and Kumi-Boateng 2019; Yildirim 2012; Şener et al. 2006); 0-110 (Gorsevski et al. 2012); 0-150 (Nas et al. 2009)

Land Use Settlements (Urban\&rural) (Karkazi et al. 2001; Lunkapis n.d.; Sadek et al. 2006; Stemn and Kumi-Boateng 2019; Chabuk et al. 2016a); Agricultural lands (Karkazi et al. 2001; Chabuk et al. 2016a; Sadek et al. 2006); forest (Stemn and Kumi-Boateng 2019)
Herb, shrub, bare land (Stemn and Kumi-Boateng 2019); Grassland, Unproductive land (Sadek et al. 2006) 
Geology Limestone (Sadek et al. 2006; Stemn and Kumi-Boateng 2019); Black dolomites(Sadek et al. 2006); Sandy(Sadek et al. 2006);

Volcanic cones with scoria(Sadek et al. 2006)

Soil $\quad$ Fluvisols- alluvial (Deniz and Topuz 2018a; Sadek et al. 2006; Stemn and Kumi-Boateng 2019); colluvial (Deniz and Topuz 2018a; Sadek et al. 2006)

Land use capability
First and Second Classes Lands (Kara and Doratli 2012; Nas et al. 2009) clayey, metamorphic deposits (Stemn and Kumi-Boateng 2019)

Ferralsols- (Stemn and Kumi-Boateng 2019); predominantly arid, alluvial (Chabuk et al. 2016b, 2016a)

Table 2

Landfill Suitability of Geology

\begin{tabular}{|ll|}
\hline Rock Type & Suitability \\
\hline Unfractured crystalline & Very high \\
\hline Shale and clay & High \\
\hline Limestone & Fair to poor \\
\hline Sandstone & Poor to very poor \\
\hline Unconsolidated sand/gravel & Unsuitable \\
\hline Source: (Oweis ve Khera, 1990 as cited in Şener 2004) \\
\hline
\end{tabular}


Table 3

Formation Criterion fuzzy membership values

\begin{tabular}{|l|l|}
\hline Formation & Membership Values \\
\hline Eşme Formation & 10 \\
\hline Musadağı Marbles & 10 \\
\hline Vezirler Melange & 7 \\
\hline Yeniköy Formation & 1 \\
\hline Dikendere Volcanics & 5 \\
\hline Küçükderbent Formation & 1 \\
\hline Karaboldere Volcanics & 5 \\
\hline Ahmetler Formation & 1 \\
\hline Beydağ Volcanics & 5 \\
\hline Ulubey Formation & 0 \\
\hline Payamtepe Volcanics & 5 \\
\hline Asartepe Formation & 0 \\
\hline Fossil and actual Alluvium \& Alluvial fans & 0 \\
\hline
\end{tabular}

Figures 


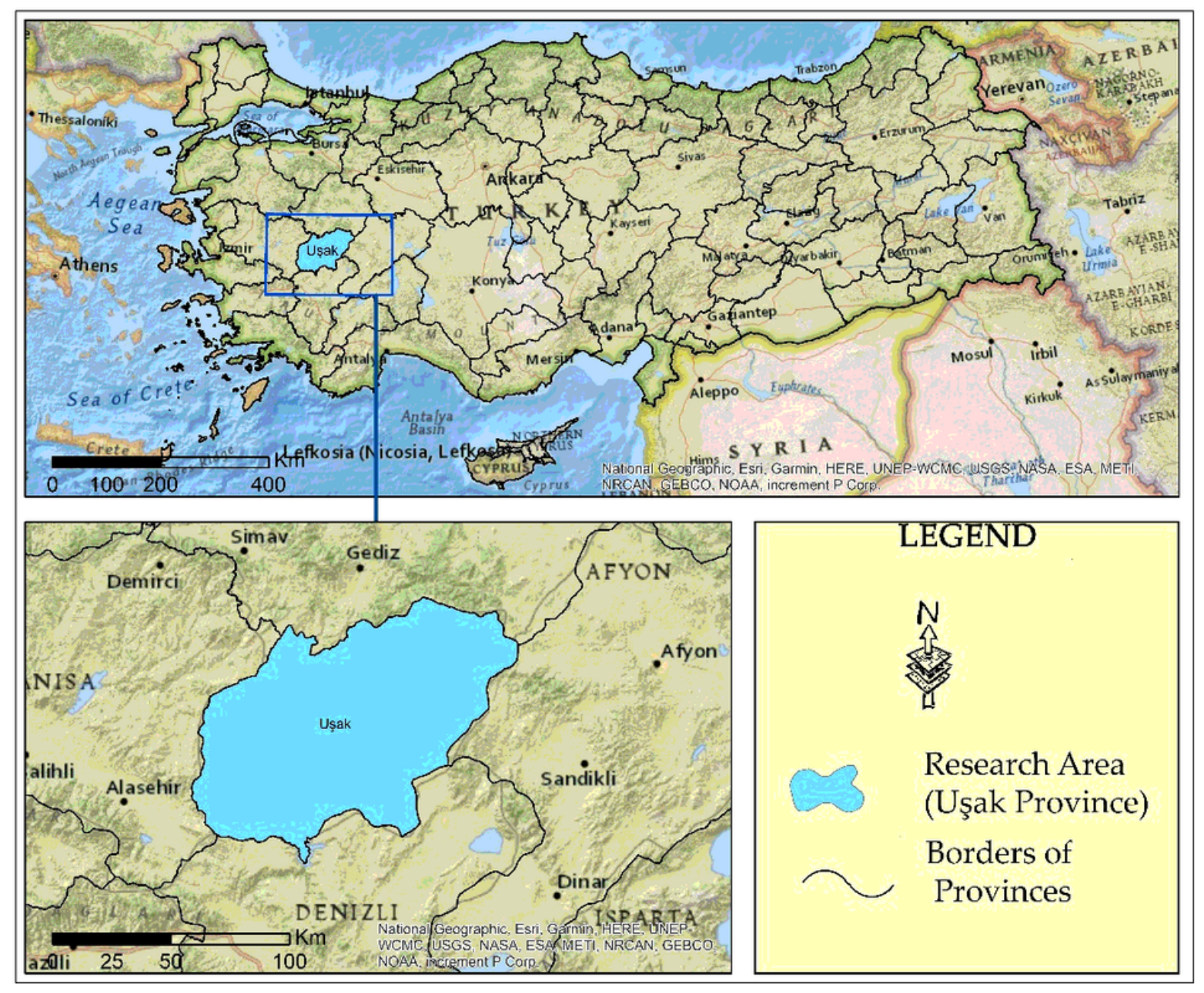

Figure 1

Location map of research area 

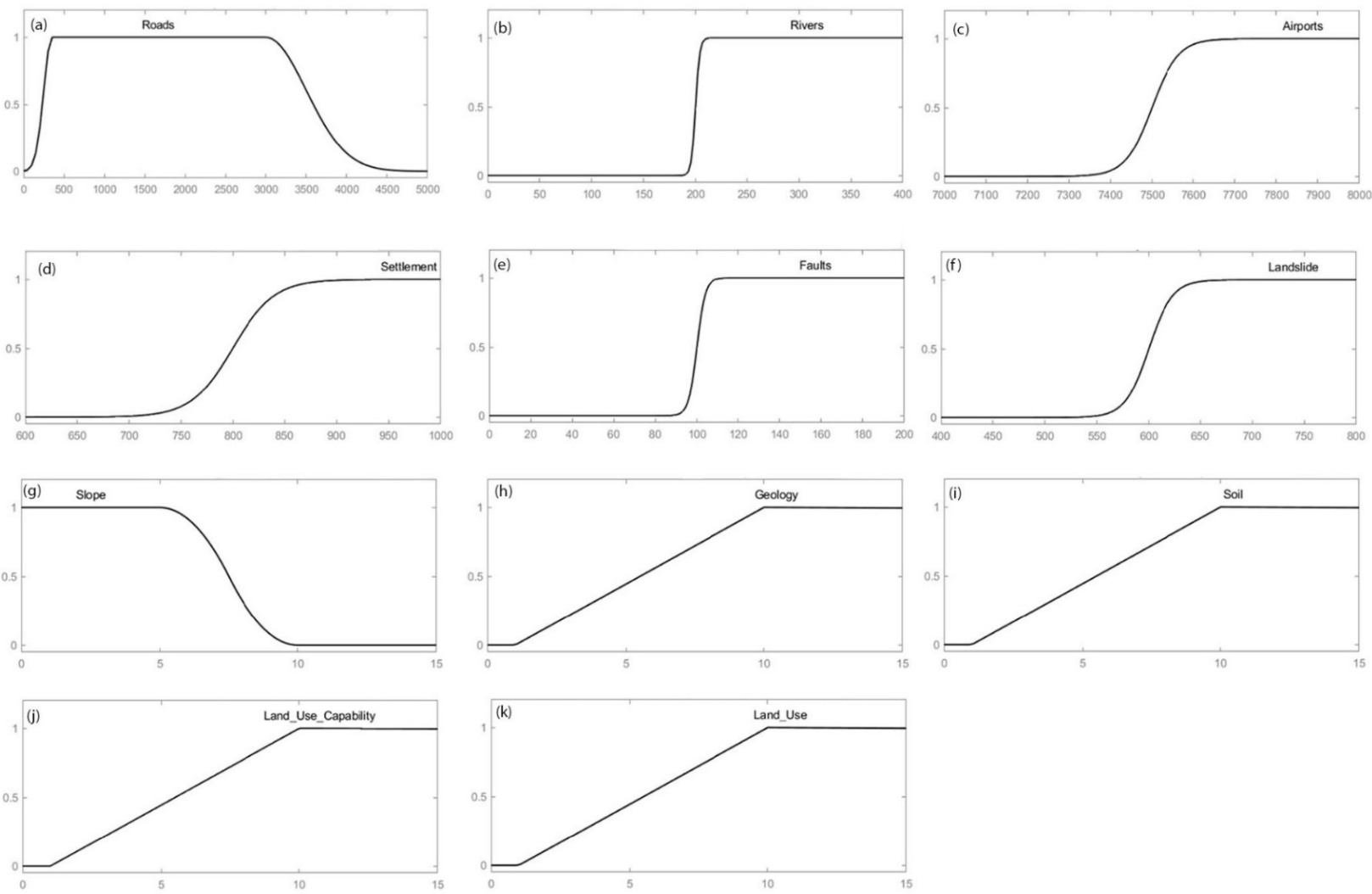

\section{Figure 2}

Fuzzy diagrams of Criteria (a) Roads (b) Rivers(c) Airport (d) Settlements (e) Faults (f) Landslide (g) Slope(h) Geology (i) Soil (j) Land use Capability (k) Lans Use 



Figure 3

Fuzzy Memberships Maps of Criteria (a) Roads (b) Rivers(c) Airport (d) Settlements (e) Faults (f) Landslide (g) Slope(h) Geology (i) Soil (j) Land use Capability (k) Lans Use 


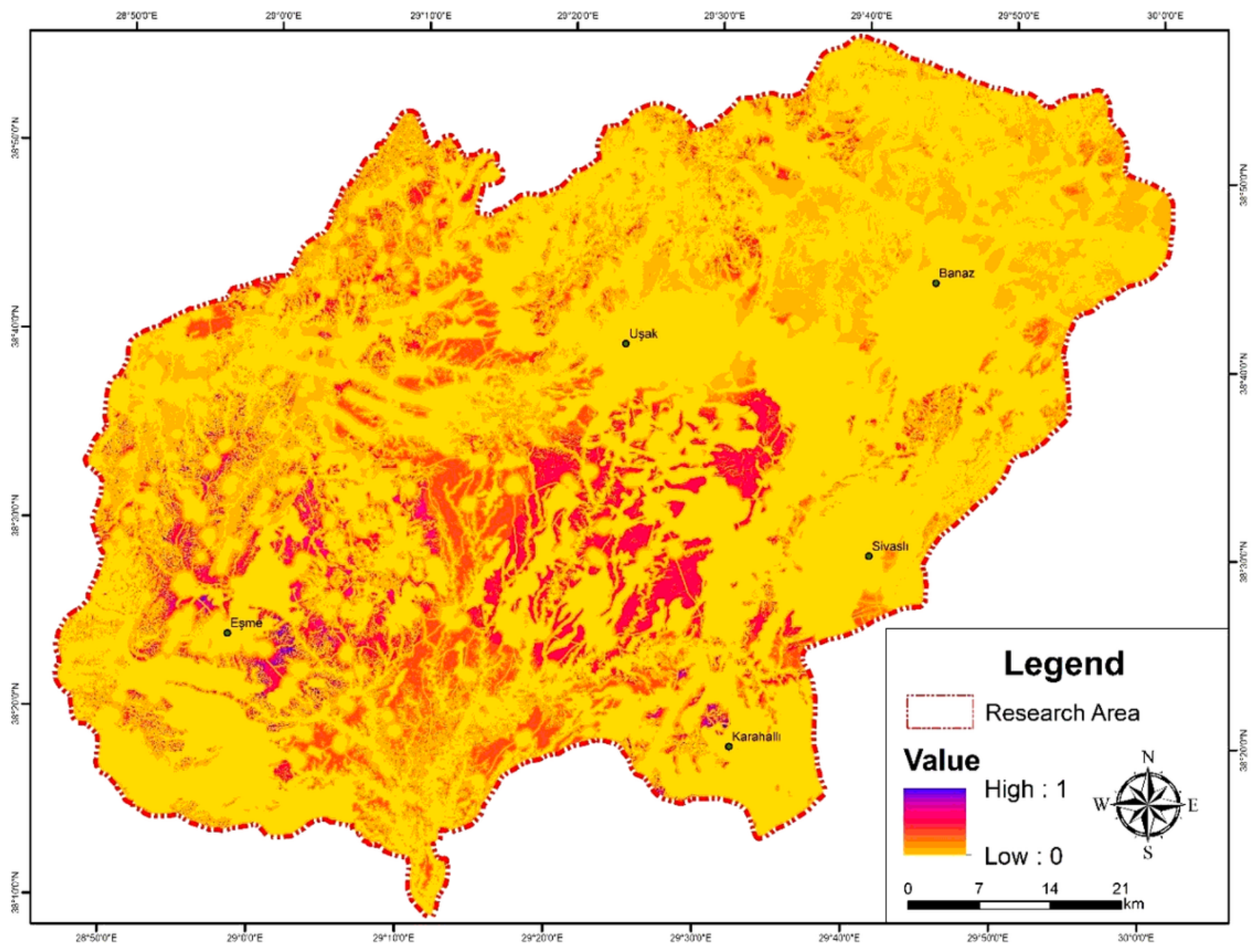

Figure 4

Optimal locations for landfill area after Fuzzy Overlay 